\title{
Tradition of foreign language teaching and learning: focusing on the Brazilian Portuguese as a Foreign Language textbook
}

\section{Tradição de ensino e aprendizagem de língua estrangeira: focalizando o livro didático de Português Brasileiro como Língua Estrangeira}

Isabel Cristina Michelan de Azevedo*

*Universidade Federal de Sergipe (UFS), Aracaju, Sergipe / Brasil icmazevedo@hotmail.com

Eduardo Lopes Piris**

**Universidade Estadual de Santa Cruz (UESC), Ilhéus, Bahia / Brasil elpiris@uesc.br

\begin{abstract}
This study addresses the concept of the tradition of foreign language teaching and learning in an attempt to consider the role of the Brazilian Portuguese as a Foreign Language (BPFL) textbook within this tradition. Therefore, based on Bornheim (1987), but also resorting to Titone (1968), Kelly (1969), Leffa (2012), and Dickey (2012), we present our concept of the tradition of foreign language teaching and learning. Thereafter, according to Foucault (1971), we analyze a BPFL textbook published in 1966 and another in 2011, focusing on activities proposed by the textbooks. Lastly, our reflection suggests that both textbooks, as an element of this tradition, turn teachers and students into domesticated subjects of the foreign language pedagogy discourse, and they do not favor language teaching practices, but rather the mechanical repetition of grammatical exercises.
\end{abstract}

KEYWORDS: Foucault; Foreign language pedagogy; Textbook; Brazilian Portuguese.

RESUMO: Este estudo trata do conceito de tradição de ensino-aprendizagem de língua estrangeira, considerando o papel do livro didático de Português Brasileiro como Língua Estrangeira (PBLE) nessa tradição. Assim, baseados em Bornheim (1987), recorrendo também a Titone (1968), Kelly (1969), Leffa (2012) e Dickey (2012), apresentamos nossa concepção de tradição de ensino-aprendizagem de língua estrangeira. Em seguida, conforme Foucault (1971), analisamos um livro didático de PBLE publicado em 1966 e outro 
em 2011, focalizando as atividades propostas pelos materiais. Por fim, nossa reflexão sugere que esses livros didáticos, enquanto elementos dessa tradição, transformam professores e estudantes em sujeitos domesticados do discurso da pedagogia de língua estrangeira e que não favorecem as práticas de ensino de língua, mas as de repetição mecânica de exercícios gramaticais.

PALAVRAS-CHAVE: Foucault; ensino-aprendizagem de línguas estrangeiras; Português Brasileiro; livro didático.

\section{Introduction}

This work aims to discuss the idea of the tradition of foreign language teaching (FLT) and learning in order to contemplate the role of the Brazilian Portuguese as a Foreign Language textbook ${ }^{1}$ (henceforth BPFL/TB) in the construction of knowledge that should be taught and learned. Our reflection mobilizes Foucault's theoretical postulates to construct an interpretation of the symbolic dimension of the processes of foreign language teaching and learning, as well as (non) discursive practices, which, over time, build knowledge about such processes, concealing the contradictions inherent to its historical constitution.

The reason to present a study on the tradition of BPFL teaching and learning is the fact that improving the quality of language teaching requires our understanding of the built and crystallized truths concerning the foreign language teaching and learning that legitimize and support the perpetuation of certain pedagogical practices, demanding from us_another view - theoretical, political, and philosophical - which involves the tradition of BPFL teaching and learning in Brazil and abroad.

In this sense, Pennycook (2006, p. 74), in justifying the use of the term "transgressive", defends the "crucial need for political and epistemological instruments to enable the transgression of the limits of traditional thought and politics", evoking thinkers, such as Foucault, to "examine our own ways of thinking, to maintain a constant skepticism in relation to the concepts and ways of thinking that we prefer" (p. 82-83). Also recognizing the relevance of Foucault's thought, Peters (2007, p. 189) states that the philosopher "offers researchers in the field of education a critical perspective based on an original theory of power."

\footnotetext{
${ }^{1}$ We take the textbook in Foucault's sense of document, i.e., as a documentary fabric in which units, sets, series, and relations are found, established by man over time.
} 
Therefore, our line of argumentation intends to show how BPLF/ TB contributes to the legitimization of knowledge that teachers and students should to be taught and learned, in an attempt to consider how the relationship between continuities and discontinuities (disruption) of teaching methods mobilized by the textbooks constitutes this tradition of foreign language teaching and learning.

Thus, this paper is divided into three stages. First, we present our reflection on the tradition of foreign language teaching and learning, specifically the tradition of BPFL teaching and learning, resorting to the concept of tradition formulated by Bornheim (1987), who, based on Foucault, postulates that disruption is a constitutive element of tradition. This makes us wonder how, despite the socio-historical changes and the technological "advances", the tradition of foreign language teaching and learning has constituted itself for centuries.

After this, we analyze historical and documentary evidence collected by Titone (1968), Kelly (1969), Leffa (2012), and Dickey (2012) in order to view distant and forgotten points of this almost immeasurable object of study, which is the tradition of foreign language teaching and learning.

Finally, we conduct our analytical reflection on the BPFL textbook, observing - through the principles of reversal, discontinuity, specificity, and exteriority (FOUCAULT, 1971) - how the textbook discourse constructs what every BPFL teacher and student should know to recognize themselves as subjects of the pedagogical practice of foreign language, which is a part of the tradition of foreign language teaching and learning.

\section{The concept of the tradition of foreign language teaching and learning}

The definition of tradition of foreign language teaching and learning formulated by Almeida Filho (1993) is rather widespread among applied linguists:

$[\ldots]$ in order to learn, students resort to conventional ways of learning typical of their region, ethnicity, social class, [since] a tradition informs [...] in a naturalized, subconscious, and implicit manner, the ways through which a new language should be learned (ALMEIDA FILHO, 1993, p. 13, our translation). 
We understand that the relation between students and tradition does not occur so directly, without being constituted by forces of sociohistorical order. We are dealing not only with choices deliberately made by students or with modes of knowledge and know-how that they are given a priori, but with a set of historically constructed rules governing the ways of producing knowledge and controlling how subjects relate to this knowledge. Out of this context, we would consider tradition to be a simple transmission of customs, from generation to generation. For Bornheim (1987), tradition can be understood:

$[\ldots]$ as the set of values within which we are established; it is not just the forms of knowledge or opinions we have, but also the totality of human behavior, which can only be elucidated based on the set of constitutive values of a given society (BORNHEIM, 1987, p. 20, our translation).

If we understand that tradition encompasses all human behavior, we certainly assume its social and historical character that establishes and consolidates the existing value systems in each epoch and the truths accepted and assumed in that society. In this sense, a quick look at the tradition of foreign language teaching and learning allows us to understand some of the activities developed in different classrooms worldwide and in textbooks produced in the past and today. Let us illustrate some of these activities in order to understand the presence of tradition.

It is common to observe that in language courses or teaching materials, organized for the basic level, there are activities based on lists of words for comparison between the two languages under study, aimed at expanding vocabulary. Western history of foreign language teaching tells us that this is one of the oldest practices that we know, the first record of which is identified in Babylon circa 2300 BC. The glossary called Harra-bubullu or Urra=hubullu (Figure 1) is an example of a list used to associate words in Sumerian - a common language among those who occupied the region of ancient Mesopotamia - and Akkadian, the language of the groups of nomads from Syria that began to penetrate the territories north of the Sumerian regions circa 2550 BC. Consisting of 24 tablets (tab.), the glossary presents lists for the following subjects: names for land and sea transport vehicles (tab. 4 and 5), names of animals (tab. 13 and 14), names of stones (tab. 16), names of plants (tab. 17), names of stars (tab. 22), revealing interest 
for topics of everyday life with a specific focus on the content related to locomotion and everyday food products.

\section{FIGURE 1 - Tablet 16 of the Urra=hubullu, Sumerian-Akkadian bilingual vocabulary ${ }^{2}$}

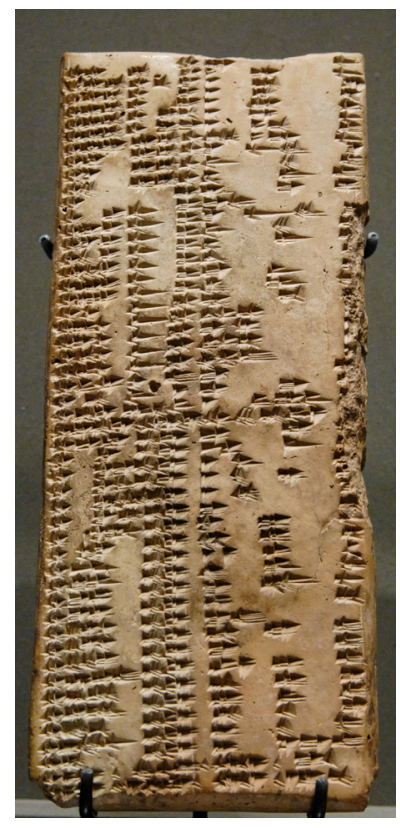

After this period, it is also very interesting to note that the Babylonian Akkadian had developed over the centuries, collaborating to the formulation of the diplomatic language of the Cannanite scribes around the middle of the $14^{\text {th }}$ century BC. During this century, many letters were sent to the Egyptian pharaohs by the rulers of Canaanite city-states. Today, researchers recognize that it possesses an elaborate linguistic system of its own. Shlomo Izre'el (2007) affirms that this is an example of institutionalized interlanguage, i.e. "a system of rules said to develop, in the mind of someone learning a foreign language, which is intermediate between that of their native language and that of the one being learned" (MATTHEWS, 1997, p. 182 apud IZRE'EL, 2007, p. 6) within a specific group, revealing

\footnotetext{
${ }^{2}$ Source: ${ }^{\circ}$ Marie-Lan Nguyen / Wikimedia Commons. Available at: <https://upload. wikimedia.org/wikipedia/commons/a/a6/Sumerian-akkadian_lexicon_Louvre_AO7662. jpg>. Retrieved on: June 23, 2015.
} 
"cultural, political, and historical understanding of the relationship between the nations and peoples in the Ancient Near East during and prior to the Amarna period" (Ibid., p. 8).

For our purpose in this study, it is important to emphasize that there were Canaano-Akkadian scribe schools "(to teach Akkadian to foreigners), that flourished all over the Near East at that period, and the linguistic features of their several vernaculars" (OPPENHEIM, 1964, p. 278-279); however, it should be noted that this was a specific teaching restricted to a community of letter writers.

Each period determines its aim according to social and intellectual factors that have little to do with scientific validity. Ends and means vary from age to age. Education is in constant movement to suit the needs of its milieu, and the various parts of education tend to lag in their reaction to social demands, so that there is always scope for reformers; and one has the impression of constant improvement when what is really happening is a constant updating (KELLY, 1969, p. 396).

Associated with economic and political motivations, we note that, in each age, the teaching of foreign languages is oriented to specific interests. In the West, the Greek education destined to bilingual tutors, slaves, and social peers consisted of teaching a foreign language, because schools did not bother with elementary language skills nor communication skills. However, it was in Rome - as there was the need to teach Greek and Latin to the entire community of the Empire - that foreign language teaching became systematic.

Although there are records of the interest of Sumerians and Egyptians in foreign language learning that date back four thousand years, we can see in the West, according to Titone (1968), that a systematic teaching methodology, which stemmed from previously produced references gathered under the title Hermeneumata Pseudodositheana, ${ }^{3}$ was only developed by the Romans in the second century. It is noteworthy that this material

\footnotetext{
${ }^{3}$ According to Dickey (2012), this material was brought to light by Georg Goetz in 1892, and gathers various texts written at different times and places that were geared to the teaching of Greek language to Latin speakers; that is why linguistic differences are observed. Texts include forewords, scenes referring to breakfast, school activities, conversations at lunch, bathing, etc. in direct dialogs or reported texts.
} 
consists of texts and guidelines for the teaching of Greek to Latin-speaking Romans; however, they could also be used to study Latin.

The Roman Empire lived a multilingual reality, so learning a second language was common, especially if we consider the extension of the occupied territory and the continuous contact between speakers of different languages. Thus, second language teaching at that time was basically guided by two objectives: a) meeting the educational needs of children of erudite Romans, who were beginning their learning process with Greeks, even before attending school, ${ }^{4}$ since it was regarded as the high culture language and b) ensuring the teaching of Latin to conquered peoples, taking into account practical and political interests.

Dickey (2012, p. 14) explains that Romans used material that taught content in different contexts, through three types of texts: conversations, literary texts, and legal texts. Conversation, proposed by dialogs organized from short sentences about everyday situations, was directed to those seeking oral proficiency. This option was supported by the understanding that:

No-one can learn a language simply by memorizing vocabulary and grammar; it is essential to experience the language in use, with the grammar and vocabulary in context. Such experience can be provided by oral conversation, and it is quite likely that many Latin learners in the Greek East had access to Latin speakers with whom they could practise in this way (DICKEY, 2012, p. 14).

The document contained simulated dialogs on different subjects, such as a morning scene, school, lunch, bathing, etc., as found in Table 1, which is similar to various proposals of "dialog" located in modern foreign language teaching textbooks.

\footnotetext{
${ }^{4}$ Wealthy and erudite Roman families hired Greek maids and nannies to initiate the education of their children before the formal studies.
} 
TABLE 1 - Excerpt from Hermeneumata Pseudodositheana III - (topic 6) ${ }^{5}$

\begin{tabular}{|c|c|}
\hline & Latin \\
\hline 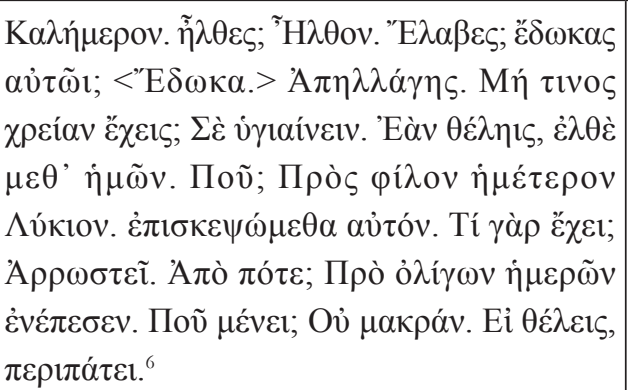 & $\begin{array}{l}\text { Bono die. venisti? Veni. Accepisti? } \\
\text { dedisti illi? Dedi. Caruisti. Numquid } \\
\text { aliquid opus habes? Te valere. Si vis, } \\
\text { veni mecum. Ubi? Ad amicum nostrum } \\
\text { Lucium. visitemus < eum>. Quid enim } \\
\text { habet? Aegrotat. A quando? Intra paucos } \\
\text { dies incurrit. Ubi manet? Non longe. Sis } \\
\text { ambula. }\end{array}$ \\
\hline
\end{tabular}

Reading of the material indicates that the dialog is constructed with reference to a common situation in Roman society: a meeting between friends who have common interests. The set of values from which their relationships are established is evident, as two friends - Caius and Lucius, two adults who appear in other texts - talk about paying a debt and worry about another colleague who was sick. Suitable for children and adults, the text simulates behaviors that were typical in Roman society at the beginning of the Christian era, thus revealing behaviors taken as appropriate to that society. On the other hand, the described culture portrays characteristics of the Roman Empire that were spreading throughout the Mediterranean world (DICKEY, 2012, p. 44).

The Hermeneumata gathers materials (basically dictionaries and texts) that can be considered foreign language textbooks, aligned to their own culture and tradition that they intended to reaffirm. The fact that titles, forewords, and texts indicate the use of everyday and not literary language

\footnotetext{
${ }^{5}$ Source: Colloquium Monacensia. Texts from four Colloquia (dialogs) are available at: <http://www.hs-augsburg.de/ harsch/graeca/Chronologia/S_post03/Dositheus/ dos_col3.html>. Retrieved on: June 18, 2015.

${ }^{6}$ Translation into English: Good Morning! You came? / I came now. / You received? You gave what they were waiting for? / I gave. / So you paid off the debt. Do you need something? You are right, if you can come with us. / At where? / To our friend Lucius. We will visit him. / What does he has? / He is sick. / Since when? / It was just a few days ago. / Where he lives? / It's not far. If you want, you walk with me.

We thank Dr. Moisés Olímpio-Ferreira for analysis and translation directly from the Greek.
} 
reinforces the practical purpose of training speakers of these languages Greek and Latin - instead of training scholars in grammar and literature.

To build a hypothesis of how the Hermeneumata was used, we can observe the variety of exercises in it. Students are advised to read the texts aloud, to memorize them and recite passages, to translate texts and produce paraphrases, to participate in dictation, to conduct reading aimed at preparing their own texts, and to answer grammar and reading comprehension questions. Young children could use the resources gathered in Colloquia, provided they were bilingual, and begin studies by learning letters and words associated with the reading of texts composed of familiar expressions, repeated aloud. Older children deepened studies by memorizing and reciting dialogs and texts, individually or in pairs, on various topics. Works relating to language in different Colloquia indicate an organization in proficiency levels, i.e., the material was organized to cater for beginners and intermediate level students of Latin (DICKEY, 2012, p. 53).

A striking similarity is observed among many of the contemporary materials used in foreign language teaching and learning, as well as these old materials, since these same kinds of activities presented in Hermeneumata are still found in textbooks of foreign language teaching today, such as in the $\mathrm{BPFL} / \mathrm{TB}$ examined in this study.

Thus, based on the study by Kelly (1969), entitled 25 Centuries of Language Teaching, we can understand the development of foreign language methods in the West throughout the centuries since the Roman Empire through two major purposes for the use of foreign language (communication versus analysis), which shifted according to the major social needs that have characterized each era (see Table 2). In this light, Kelly (1969) argues that the regular changes of three broad aims - (i) the social, (ii) the artistic or literary, and (iii) the philosophical - demand language to be regarded in different ways: (i) as a form of social behavior and a type of communication; (ii) as a creative activity; (iii) as an object of analysis (Ibid., p. 396). Therefore, according to Kelly (1969, p. 397):

At each period in history one of these has become predominant, generating its own approach to method. It is the regular chancing of these aims that produced the cyclic progression which is such a noticeable feature of language-teaching development. The classical, Renaissance, and modern periods have enough points of similarity to allow us to contrast them with the 
Middle Ages and the age of reason. The basic aim of the first group was communication (with the other aims subordinated), while the other periods aimed at analysis above all else.

TABLE 2 - Timeline of development of the foreign language methods in the West

\begin{tabular}{c|l}
\hline Ages & \multicolumn{1}{c}{ Social purposes and their consequences } \\
\hline Classical Rome & $\begin{array}{l}\text { Greek was taught for a range of purposes from social chitchat to the } \\
\text { transmission of literary and philosophical thought (Ibid., p. 397). }\end{array}$ \\
\hline Middle Ages & $\begin{array}{l}\text { Latin was taught as a highly sophisticated vehicle of argument and artistic } \\
\text { creation. Theology and philosophy demanded close attention to the } \\
\text { intricacies of grammar (Ibid., p. 398). }\end{array}$ \\
\hline Renaissance & $\begin{array}{l}\text { Latin was an obligatory knowledge for the educated elite. Modern foreign } \\
\text { languages became literary vehicles of some stature, but they were taken } \\
\text { as primarily social implements. In scholarship, they merely had a curiosity } \\
\text { value and were not considered to have the lasting power necessary for } \\
\text { literature (Ibid., p. 397). }\end{array}$ \\
\hline $\begin{array}{c}\text { Age of reason } \\
\left(17^{\text {th }}, 18^{\text {th }} \& 19^{\text {th }}\right. \\
\text { centuries })\end{array}$ & $\begin{array}{l}\text { Grammar-translation evolved due to logical orientation of grammar, } \\
\text { displacing the social purposes of language to a secondary role. } \\
\text { “The Cartesian attitude emphasized once again the science of grammar, } \\
\text { reducing quite considerably the role of rhetoric" (Ibid., p. 402-403). }\end{array}$ \\
\hline $\begin{array}{c}\text { Modern period } \\
\left(19^{\text {th }} \& \text { early } 20^{\text {th }}\right)\end{array}$ & $\begin{array}{l}\text { "Reaction against written methods in a situation imposing an oral aim } \\
\text { produced a rigid stand in favor of approaches through the spoken } \\
\text { language" (Ibid., p. 403). }\end{array}$ \\
\hline
\end{tabular}

Source: Kelly (1969, p. 394-408).

Thus, in order to understand a particular tradition of foreign language teaching and learning, it is important to identify features of continuity and discontinuity (disruption) of this development of foreign language teaching methods and its historical legacy. From the point of view of our concept of tradition, we can understand these historical movements - while continuities and discontinuities pointed to different periods and regions of the worldas evidence of how the tradition of foreign language teaching and learning is constituted by opposing forces that mutually attract, a principle thus observed by Bornheim (1987, p. 15):

In reality, everything happens as if one of the terms could not be without the other. Attraction, therefore, but also mutual repulsion as each term is only affirmed 
to the extent of its opposite. Tradition just seems to be imperturbably itself to the extent that it avoids any possibility of disruption, it seeks to be perennial and eternal, without realizing that the lack of movement ultimately dooms it to the stagnation of death. The necessity of disruption becomes, therefore, imperative to restore dynamism to that which seemed "lifeless".

In this sense, we can affirm that - despite the incidence of interruptions, i.e. disruptions that cause discontinuities - tradition remains strong, because reality can only be understood from the opposition of contraries in which a mutual attraction and repulsion is observed.

In short, we can understand that the tradition of teaching and learning a foreign language is constituted by the discourses that have circulated in society about foreign language learning for a long time, "in the great continuities of thought, in the solid, homogeneous manifestations of a collective spirit or mentality [...] passionately fighting to exist and to be perfected since its inception.” (FOUCAULT, 1969, p. 4)

\section{The textbook in the tradition of Brazilian Portuguese as a Foreign Language teaching and learning}

\subsection{Methodological principles for analysis}

The role of discourse analysts is to provide principles of analysis that enable the understanding of power relations that are sociohistorically established. In this sense, in carrying out the analysis of two textbooks that are relatively distant from each other in time and in observing the relations between the heterogeneous elements (discursive and non-discursive), we intend to emphasize three points.

- The construction of knowledge in the textbook;

- The reasons that define how to teach and learn, including procedures that simulate social practices of language;

- The processes of domination of behaviors and discourse objects.

Our analysis of the tradition of BPFL teaching and learning emphasizes the textbook discourse in order to criticize language teaching practices, as well as to understand the web that entangles and, at times, paralyzes our teaching practices. Thus, to analyze the conditions of the 
constitution of discourses, their games and effects, we adopted a theoretical and methodological approach based on the principles recommended by Foucault (1971): reversal, discontinuity, specificity, and exteriority.

Our analysis adopts an attitude of "suspicion" towards the way content is presented in textbooks. According to Foucault (1967), the masters of suspicion - Marx, Nietzsche, and Freud - established a new way of interpreting the signs, not seeing them as signifiers that refer to a meaning, but reading them in a new way.

From this perspective, interpretation is an eternal game of mirrors and assumes an existential and ontological character for man. It is the "unfinished of interpretation" that can be perceived. Interpretation never ends because "there is nothing to interpret, nothing is absolutely first to be interpreted, since, in the end, everything is already interpretation; each sign is in itself not the thing that is offered to interpretation, but the interpretation of other signs" (FOUCAULT, 1967, p. 47). "The sign is already an interpretation that does not occur as such, signs are interpretations that try to justify themselves, and not the opposite" (Ibid., p. 48). In other words, interpretation is always an act that implies a reflection of itself, that is, the interpretation endlessly confronts the constitutive obligation to interpret itself, that is, to continuously readdress itself.

Therefore, considering that our analysis here is an interpretation of so many other interpretations, the analysis of the textbook discourses is based on the following methodological principles formulated by Foucault (1971, p. 51-53):

- Principle of reversal - the sources are points of dispersion of discourses, which constitutes its rarefaction, i.e., there is no source of discourses;

- Principle of discontinuity - discourses are discontinuous practices in which they mutually intersect, ignore, and exclude;

- Principle of specificity - the discourse is not a game of previous meanings, but a practice that is imposed through regularities;

- Principle of exteriority - the discourse has its appearance conditions, its external conditions of possibility, which can be observed in the discourse itself. 
These principles of analysis guide the observation of regularities, disruptions, strategies of rarefaction of discourses, and as well as the possibilities of analyzing the role of the BPFL/TB in the tradition of foreign language teaching and learning.

\subsection{The construction of knowledge in the BPFL/TBs}

To illustrate our reflection, we selected some enunciations ${ }^{7}$ that constitute the discourse of the BPFL/TBs Português Contemporâneo [Contemporary Portuguese], with the first edition published in 1966, and Fala Brasil: português para estrangeiros [Speak Brazil: Portuguese for foreigners], with the $17^{\text {th }}$ edition published in 2011 . The selection of excerpts that are relatively far apart in time allows us to show the regularities and disruptions present in these discourses and the construction of knowledge about the conceptions of language and foreign language teaching.

The BPFL/TBs contain oral expression activities in a foreign language in the form of texts that simulate conversations between native speakers in everyday interaction situations, producing an effect of meeting the specific needs that, presumably, the speaker of another language will have in Brazil.

Let us observe an excerpt from Português Contemporâneo:

\section{FAZENDO COMPRAS}

Helena e Carlos

H: Eu me sinto exausta mas tenho que fazer compras. Vamos à cidade?

C: Você não prefere comprar aqui mesmo no bairro? Você não disse que aqui há de tudo, que não falta nada?

H: Qualquer lugar serve. Eu quero ver muitas lojas.

GOING SHOPPING

H: I'm exhausted but I have to go shopping. Let's go downtown.

C: Don't you want to shop right here in the neighborhood? You always say that you can find everything here, don't you?

H: Any place will do. I want to see many stores.

(ABREU \& RAMEH, 1966, p. 319)

\footnotetext{
${ }^{7}$ According to Foucault (1969), unlike the phrase, which is relevant to all speakers of the language, enunciation comes from the position assumed by the subject in an institutional place, so it is determined by sociohistorical rules. As it assumes various functions, it allows for the emergence of concrete contents in time and space.
} 
In this textbook, in both volumes, every unit begins with a dialog that is always presented in Portuguese and English. We undertand it is because of the orality intended in the textbook that the sentence structure is formal and does not correspond to the typical uses of oral language. We also note that the topic discussed serves as a reference for the entire unit. In the first volume there are 22 units and in the second another 20, which deal with a variety of subjects (Table 3 ).

TABLE 3 - Titles of the dialogs from Português Contemporâneo

\begin{tabular}{|c|c|c|c|}
\hline \multicolumn{2}{|r|}{ Volume 1} & \multicolumn{2}{|r|}{ Volume 2} \\
\hline p. 11 & Introductions & p. 287 & Helena's engagement \\
\hline p. 21 & Language and nationality & p. 305 & Dining out \\
\hline p. 31 & At a party & p. 319 & Going shopping \\
\hline p. 47 & At Dona Amelia's house & p. 333 & Clothes for Betinho \\
\hline p. 59 & Waiting for the family & p. 349 & Life in Juiz de Fora \\
\hline p. 73 & Lunchtime & p. 367 & Barren lives \\
\hline p. 85 & Leaving for Brazil & p. 383 & A soccer game \\
\hline p. 97 & At the club & p. 401 & Preparing for the entrance exam \\
\hline p. 109 & At the outdoor market & p. 417 & The hairdresser's \\
\hline p. 121 & Climate in Brazil & p. 431 & Getting ready for guests \\
\hline p. 131 & Getting ready for school & p. 449 & Vacation on the ranch \\
\hline p. 139 & John's day & p. 471 & A good job \\
\hline p. 149 & The Portinari painting & p. 495 & Leaving for Recife \\
\hline p. 163 & The state of Guanabara & p. 517 & In the barber shop \\
\hline p. 175 & A paulista and a carioca & p. 535 & A trip south \\
\hline p. 187 & An appointment at the ministry & p. 557 & Tio Juca's stories \\
\hline p. 203 & Brazilian history & p. 577 & Tiradentes' day \\
\hline p. 217 & Betinho's birthday & p. 597 & The two empires \\
\hline p. 231 & Finding an apartment in Copacabana & p. 615 & Newspapers of Brazil \\
\hline p. 243 & A trip to Brasilia & p. 631 & At the concert \\
\hline p. 253 & At the doctor's office & & \\
\hline p. 267 & The Brazilian flag & & \\
\hline
\end{tabular}

Source: Abreu \& Rameh (1966).

All topics in volume 1 are associated with everyday life situations, while in volume 2 , the last four units address historical issues. They are circumstances that may interest American women and men who come to 
visit Brazil, because they meet the need for purchases and the use of services, as well as indicate places to visit, to enjoy, etc. The dialogs are the central element in the Fala Brasil textbook, since it is the guiding axis of the units. There is no single theme in each of them, because "situations" and "guided dialogs" deal with a variety of subjects, for example:

NA LOJA

Vendedor: Pois não?

Cliente: Eu estou precisando de um fogão. Gostaria de ver alguns.

Vendedor: Sim, senhora. Temos vários modelos.

Cliente: Quanto custa esse azul?

Vendedor: Esse aqui?

Cliente: É.

Vendedor: À vista custa $\mathrm{R} \$ 230,00$.

Cliente: Puxa, que caro!

Vendedor: Estamos fazendo uma promoção em três prestações sem entrada...

- Posso ajudar?

- Obrigada. Estou só olhando.

- Pois não? Posso ajudar em alguma coisa?

- Bom dia. A senhora tem algum livro sobre a Amazônia?

- Temos alguns, mas esse aqui é o melhor. As fotografias são incríveis.

- É. É lindo mesmo. Vou ficar com ele. A senhora podia embrulhar para presente?

- Eu gostaria de experimentar essa calça, por favor.

- Pois não. A cabine (o provador) é algo ali. [alguns minutos depois...]

- Moça, tem um número maior? Essa ficou um pouco curta.

- Um momento. Vou buscar... Tem sim, mas é de outra cor.

- Tudo bem.

(COUDRY \& PATROCÍNIO, 2011, p. 79).

Our translation into English:

AT THE STORE

Salesman: Can I help you?

Customer: I need a stove. I'd like to see some models.

Salesman: Ok, ma'am. We have many models.

Customer: How much for this blue one?

Salesman: This one?

Customer: Yeah.

Salesman: It's R\$230. 
Customer: Gosh, so expensive!

Salesman: We're having a sale, so we're offering store financing in three installments, with the first to be paid in 30 days...

- Can I help you?

- Thank you. I'm just looking around.

- Can I help you?

- Good morning. Do you have any books about Amazonia?

- We have many books, but this is the best. Its photographs are amazing!

- Yeah. It's really wonderful. I'll take it. Could you gift-wrap it?

- I'd like to try on those pants, please.

- May I help. The booth is right there. [A few minutes later ...]

- Miss, do you have this in a larger size? That one was a little short.

- Just a moment. I'll get it ... Yes, but it's another color.

- It's all right.

This excerpt from Fala Brasil indicates that the textbook aims to promote communication between people in a particular situation, constructed (according to the authors in the Presentation) to insert the language structure in verisimilar contexts. The dialogs also have usual language with some variations and a variety of subjects. The "Guided dialogs" are present in all units in different quantities (unit 1: page 5; unit 2: pages 21, 25 and 27; unit 3: page 43; unit 4: page 51; unit 5: pages 65, 69 and 74; unit 6: pages $84,85,87$; unit 7: page 102; unit 8: page 122; unit 9: page 128; unit 10: page 145; unit 11: page 167; unit 12: page 183; unit 13: pages 199 and 203; unit 14: page 218 and 219; unit 15: page 228). To the extent that the knowledge of Portuguese progresses, the number of direct dialogs decreases. From unit 10 on, they also begin to serve to practice language structures. Each communication situation deals with different topics and appears in different formats (see Table 4). 
TABLE 4 - Situations in the textbook Fala Brasil

\begin{tabular}{|c|c|c|c|}
\hline Unit & Page & Situations & Topics $^{8}$ \\
\hline 1 & 3 & Situation 1 & Cumprimentar/To greet \\
\hline 1 & 6 & Situation 2 & Apresentar/To introduce \\
\hline 1 & 8 & Situation 3 & Identificar/Identify \\
\hline 1 & 12 & Situation 4 & not mentioned \\
\hline 2 & 15 & Situation 1 & Eu queria.../I would like... \\
\hline 2 & 20 & Situation 2 & Comprar/To buy (to ask for, to ask the price) \\
\hline 2 & 24 & Situation 3 & Depois da feira/After the street market \\
\hline 2 & 26 & Situation 4 & not mentioned \\
\hline 3 & 31 & Situation 1 & Você podia?/Could you? \\
\hline 3 & 37 & Situation 2 & Onde?/Where? \\
\hline 3 & 41 & Situation 3 & Cores/Colors \\
\hline 4 & 49 & Situation 1 & Alô?? \\
\hline 4 & 54 & Situation 2 & Pedindo informações na rua \\
\hline 5 & 63 & Situation 1 & $\mathrm{Na}$ agência de viagens \\
\hline 5 & 67 & Situation 2 & Viajando \\
\hline 5 & 71 & Situation 3 & No restaurante do hotel \\
\hline 6 & 79 & Situation 1 & Fazendo compras \\
\hline 6 & 89 & Situation 2 & No banco \\
\hline 6 & 91 & Situation 3 & Comparando \\
\hline 7 & 97 & Situation 1 & No hospital \\
\hline 7 & 101 & Situation 2 & Consultando \\
\hline 8 & 118 & Situation 1 & No trabalho \\
\hline 9 & 125 & Situation 1 & No posto de gasolina \\
\hline 11 & 162 & Situation 1 & No cabeleireiro \\
\hline 11 & 163 & Situation 2 & Alugando um apartamento \\
\hline 12 & 186 & Situation 1 & Emergência \\
\hline 14 & 214 & Situation 1 & associated with the chronic "No restaurante" \\
\hline
\end{tabular}

Source: Coudry \& Patrocínio (2011).

${ }^{8} \mathrm{Up}$ to unit 3 , the topics in question in each communicative situation are presented in Portuguese, English, and French, but in this table, they are only indicated in two languages.

${ }^{9}$ From this unit on, the topics are indicated only in Portuguese. 
The communicative situations selected for the book highlight everyday circumstances and present linguistic variation, as we pointed out in the guided dialogs. The two types of activities serve to study the linguistic structures, which is carried out in the part entitled "systematization".

Considering that we have had records of this type of didactic activity since the Hermeneumata, we observe that the teaching of oral expression in a foreign language through simulated dialogs is a practice that has been carried out regularly (according to the principle of specificity) for at least 1800 years, which contributes to the construction of the tradition of foreign language teaching and learning.

Along with the principle of specificity, we observe the principle of reversal, since we may not know the exact origin of the chosen subjects, but we perceive that they collaborate with the rarefaction of the discourses over time. For example, in the Latin text, Hermeneumata Pseudodositheana III - Colloquium Monacensia, and in the two books of Portuguese for foreigners, Português Contemporâneo and Fala Brasil, there is heavy emphasis on the interactional exchanges that occur at lunch. We do not know if some day these dialogs would have happened exactly in the way that they were transcribed or what people were involved in them, because the important thing is to guarantee contact with situations that can happen with foreign language students, reinforcing a model of teaching and learning.

Thus, let us observe this excerpt from Hermeneumata Pseudodositheana III-Colloquium Monacensia:

[...] ut haec egimus, dimisit ad prandium. dimissus venio domi. muto, accipio panem candidum, olivas, caseum, caricas, nuces. bibo aquam frigidam. pransus revertor iterum in scholam. invenio magistrum perlegentem, et dixit: Incipite ab initio. ${ }^{10}$

Christopher Francese, Professor of Classical Studies at Dickinson College (USA), offers the following translation into English:

When we had done these things, he let us out for lunch. Having been let out, we go back home. I change, I take fresh bread, olives, cheese, dried figs, nuts. I drink

\footnotetext{
${ }^{10}$ This excerpt is available in both Greek and Latin at Bibliotheca Augustana website: https://www.hs-augsburg.de/ harsch/graeca/Chronologia/S_post03/Dositheus/ dos_col3.html.
} 
cold water. After lunch I go back to school. I find the teacher rereading lessons. And he said: Begin from the beginning. ${ }^{11}$

We observe this kind of dialog updated in BPFL/TB, beginning with the Português Contemporâneo textbook:

À hora do almoço

Dona Amélia: Você deve estar com fome, Alceu. O almoço hoje está tão atrasado.

Doutor Alceu: Não faz mal, Amélia. Eu como bem a qualquer hora.

Dona Amélia: Você quer arroz com feijão?

Doutor Alceu: Quero, sim; e também um pouco destas batatas. Elas estão parecendo boas. [...]

Lunchtime

Miss Amélia: You must be hungry, Alceu. Lunch is so late today.

Dr. Alceu: That's all right, Amélia. I can eat any time.

Miss Amélia: Do you want rice and beans?

Dr. Alceu: Yes, I do. And also some of these potatoes. They look good.

$[\ldots]$

(ABREU \& RAMEH, 1966, p. 73)

In turn, we can observe the same type of didactic activity in the Fala Brasil textbook:

Situação 3 - No restaurante do hotel

$[\ldots]$

Garçom: Olhe aqui o cardápio.

Marta: Nossa! Quantos pratos diferentes! Nem sei o que escolher.

Sérgio: Eu acho que vou experimentar esse peixe... Parece bom.

Elisa: Estou sem fome... Vou querer só uma salada.

Paulo: Gente, que tal experimentar um prato típico da região?

Todos: É, boa ideia!

Marta: Vamos pedir também uma porção de batatas fritas e outra de farofa. Sérgio, Garçom, por favor.

(COUDRY \& PATROCÍNIO, 2011, p. 71).

${ }_{11}$ Translation available at: http://wiki.dickinson.edu/index.php?title=Colloquia_ Monacensia. 


\section{For this excerpt, we elaborate the following translation into English:}

Situation 3 - In the hotel restaurant

$[\ldots]$

Waiter: Here is the menu.

Marta: Wow! Many different dishes! I don't know which one to choose from.

Sérgio: I think I'll try this fish ... It looks good.

Elisa: I'm not hungry ... I'll just have a salad.

Paulo: Guys, what about trying a typical regional dish?

All: Yeah, good idea!

Marta: Let's also order a portion of French fries and another one of farofa.

Sérgio: Waiter, please.

As Bornheim (1987) explains, tradition does not persist through time only due to the mere repetition of practices because, paradoxically, the movements of disruption renew traditional practices, without necessarily having to forsake them. In this sense, the pedagogical practices acquire different meanings throughout history. For example, if on the one hand, the dialogue composition structure is repeated regularly in the excerpts from the textbooks, on the other hand, various proposals of didactization of these dialogs are formulated in the textbooks' discourses. Remembering what Kelly said: "old approaches return, but as their social and intellectual context are changed, they seem entirely new" (KELLY, 1969, p. 396).

Thus, considering only the period of 45 years between the publication of Português Contemporaneo and Fala Brasil, we find the principle of discontinuity. However, broadening our horizon of observation, we can highlight other points of discontinuity and disruption in this tradition of teaching.

In Português Contemporâneo, dialogs are followed by a translation into English, assuming that the textbook's target audience is a speaker of that language. As the intention is not to teach a foreign language through translation, we cannot say that there is affiliation to the translation method discourse, but it is also undeniable that this activity allows the student to achieve the target language through another language already acquired, which supports learning. The bilingual presentation of dialogs in Português Contemporaneo proves to be a point in history, in which the translation method discourse finds its rarefaction. 
In Fala Brasil, on the other hand, activities with dialogs are part of the continuing foreign language teaching practices in $17^{\text {th }}$ century Western Europe under the Direct Method, because there is a target language teaching practice through the target language, that is "meaning is to be conveyed directly in the target language through the use of demonstration and visual aids [...]" (LARSEN-FREEMAN, 2000, p. 23).

In this ambivalent relationship, we identify how contradictory forces act in the construction of discourse, finding, at the same time, the principle of specificity in the repetition of the dialog resource, as well as the principle of discontinuity in the adaptations conducted to teach a foreign language through dialogs.

In addition to the regularities and discontinuities constituting the textbook's discourses, we also need to listen to the external conditions of possibility of discourse.

In the pedagogical proposal of Português Contemporâneo, contained in the textbook's presentation text, the discourse of a teaching method based on the formalist conceptions of language and traditional concepts of teaching is materialized through the excerpt:

A dialogue. Each lesson is built around a short and realistic dialogue which provides examples of the structures to be studied and serves as the basis for drills. The dialogue should be thoroughly memorized by the student. It should be learned first in class, then in the laboratory, and finally it should be repeated by the student with the book closed. The student should only look at the written page after memorization has been attained (ABREU \& RAMEH, 1966, p. vi).

This discourse contributes to constructing a kind of knowledge about foreign language teaching and learning that disciplines teachers and students to direct efforts to the formal structures of the target language through structural exercises. The set of knowledge built on the concept of foreign language teaching assumes and constitutes, at the same time, relations of power, which are reinforced by the academic-scientific discourse of Linguistics, which, in turn, strives to perpetuate the formalistic conception of language. It is a more complex network than the one we are describing briefly. 
In the 1960s, post-structuralism began to intensely question the concept bases of Structuralism, but Formalism (Structuralism and Generative Linguistics) was still considered the hegemonic discourse in Linguistics, while Applied Linguistics was still conceived as the application of knowledge from Linguistics to foreign language teaching. These external conditions of possibility of appearance of the Português Contemporaneo discourse about what learning a language is, can be recognized in the following excerpt from the textbook:

[...] Knowing a language can be defined as the capacity of using its complex mechanism by having internalized its phonological, morphological, and syntactical rules plus the foreign language lexicon [...] (ABREU \& RAMEH, 1966, v, our emphasis).

However, in Fala Brasil discourse, we observe the inscription of a dispute in the academic institution for knowledge - thus, for power between Applied Linguistics and Linguistics ${ }^{12}$ through the excerpt:

$[\ldots]$ The directed dialogs are the link between the simple capacity to conjugate the verbs and the capacity to use them in practical situations [...]. The dramatization of these dialogs is an ideal method to increase vocabulary and to learn to use of idiomatic expressions [...] (COUDRY \& PATROCÍNIO, 2011, Presentation).

By the principle of exteriority, we recognize that the global spread of the communicative approach is one of the external conditions of the possibility of appearance of Fala Brasils discourse. To legitimize itself, the textbook discourse not only announces the tenets of the adopted teaching approach, but also disqualifies the competitor approach. In this case, the

\footnotetext{
${ }^{12}$ Moita Lopes (2009) historicizes the Applied Linguistics constitution process as an interdisciplinary and independent field of knowledge of linguistics, emphasizing a path of reconstructions characterized by the following turning points: (i) application of linguistics to foreign language teaching; (ii) criticism to applicationism and the proposal of an interdisciplinary model based on the user's perspective; (iii) language studies in the school's different institutional contexts; (iv) reflection on language and social practices from the perspectives of INdisciplinary, Critical, or Transgressive Applied Linguistics.
} 
authority to qualify itself and disqualify the other comes from the academic institution, from an exteriority, when, for example, the scientific discourse of an applied linguist, like Widdowson (1978, p. 37-38), elaborates a statement such as: "The teaching of use, however, appears to ensure the learning of forms since the latter are represented as necessary parts of the first. That being so, it should be wise to plan language teaching courses focused on use."

The opposition between form and the use of language embodies the dispute between Linguistics and Applied Linguistics, as well as the dispute between Formalism and Functionalism; hence, the concept of language is the discursive object in dispute. The construction of new knowledge about what language is and how to teach it constitutes Applied Linguistics as a theoretical and methodological research field that is separate from linguistics.

The formation of a network of discourses (academic, educational, editorial, etc.) triggered by scientific discourse appears as a disruption in the tradition of teaching and learning a foreign language. Academic events on Applied Linguistics are organized and books on this theme are published as the foundation for foreign language textbooks, forming a new intelligence on the subject. This network, therefore, integrates and renews the FLT dispositive. These are some external conditions of appearance of discourses about what learning a language is, such as that from Fala Brasil: "Grammar is, for us, an instrument that helps the student to communicate. [...] The highlight of Fala Brasil is the systematization based on the effective use of the language" (COUDRY \& PATROCÍNIO, 2011, our emphasis).

Thus, the discourse of Português Contemporâneo builds its legitimacy according to the knowledge of Linguistics (Structuralism and Generative Linguistics), whereas the formulation of enunciations in Fala Brasil joins the knowledge from the communicative approach. The discourse of both textbooks reproduces the value of the "use of language", but the purpose of Português Contemporâneo is the internalization of linguistic rules, while Fala Brasil focuses on communication, which differs one from the other.

The aim of favoring the internalization not only of rules, but also of the meaning of new words, is visible in the proposal of vocabulary enhancement through word lists, a practice that has been observed since $2300 \mathrm{BC}$ and which is still present in the textbooks under study (Table 5). Although supported by various foundations, the procedures adopted in the textbooks reveal that the rarefaction of discourse no longer allows us to recognize the source of discourses, thus establishing the principle of reversal. 
TABLE 5 - Activities directed to the study of vocabulary

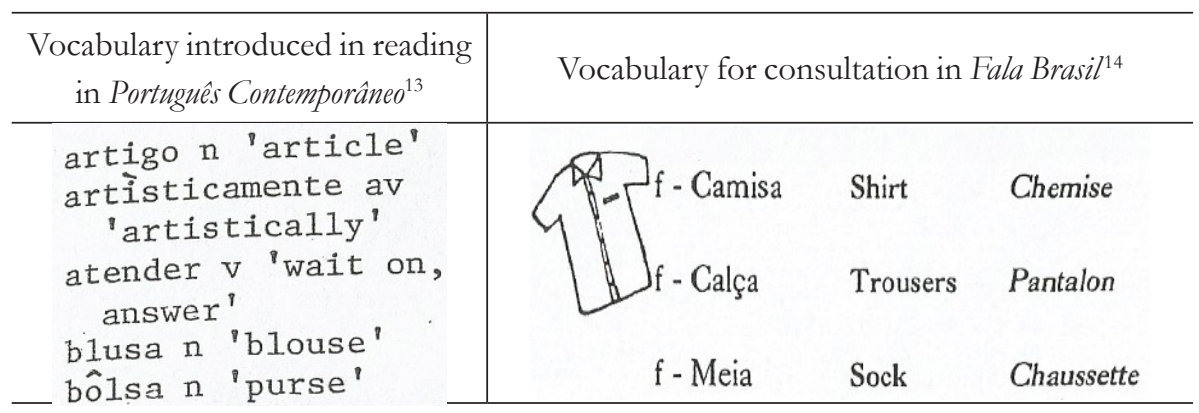

Source: Abreu \& Rameh (1966, p. 331); Coudry \& Patrocínio (2011, p. 82).

Thus, even though the discourse of each textbook identifies with one or another FLT approach, the enunciations in Table 5 are constructed in the continuity of the same historical path - consider the bilingual SumerianAkkadian vocabulary Urra-bubullu dated 2300 BC (Figure 1). As we have said, these bilingual lists allow students to access, through translation, the meanings of the target language through the already known meanings of an acquired or learned language. In discussing the historical evolution of FLT methods, Leffa (2012) considers that, in the translation method, "it was produced [...] the strange effect of speaking in one language and thinking in another", pondering that "with practice, the processing of the two steps could become faster, even creating the illusion of a single step" (LEFFA, 2012, p. 395).

Regardless of the value judgment that is made of this method, the question is: why has a pedagogical practice, such as educational activities based on translation, been recurrent for at least 4300 years? Numerous

\footnotetext{
${ }^{13}$ In all volume 1 , the study of vocabulary is linked to the structural exercises of language study; only in volume 2 are the activities of reading (in all 20 units), in which the section entitled "vocabulary introduced in reading" is located (pages: 302, 317, 331, 347, 363/364, 380/381, 397/398, 414/415, 429, 445/446, 468/469, 493, 514/515, 532, 553/554, 573/574, 593/594, 611-613, 628/629, and 647-649).

${ }^{14}$ The section "Vocabulary for consultation" is introduced in unit 2 and appears in the textbook until unit 6, always in three languages (Portuguese, English and French). The mobilized themes inlcude: Alimentação/Foods (unit 2, page 28), Material de limpeza/ Cleaning (unit 3, page 35), Partes da casa/Parts of the house (unit 3, page 40), Cores/ Colors (unit 3, page 41), Mesa e cozinha/Table and kitchen (unit 5, pages 71-73), Móveis / Furniture (unit 6, page 79), and Roupas/Clothes (unit 6, page 82).
} 
explanations could be suggested; however, it seems this is one of the examples of the strength of tradition that resists time due to its strategic role in the FLT dispositive: dictionaries and phrase guides (phrasebooks) are sold, they make a student believe that learning language is learning lists of words, methods are sold with foolproof tips for fast learning, and finally a set of knowledge is constructed that pushes those interested in learning a second language into becoming docile subjects of this discourse, stigmatizing those who do not accept the adoption of this order of discourse. Moreover, for teachers, the only choice is to execute the method, to ensure its popularity in the course, and therefore its implementation.

For all that was said up to this point, we affirm that the legitimacy of the PFL/TB discourse is associated with the contradictory force of tradition/disruption of teaching and learning a foreign language, whose knowledge and powers perpetuate the FLT dispositive, this mechanism of domination.

\section{Final considerations}

Considering the critical suspicion proposed by Foucault (1967), and defended by Pennycook (2006) and Peters (2007), we would like to delineate the conclusion of our reflection, leaving some questions and sharing some concerns that may raise new discussions about the processes of constructing the tradition of teaching and learning a foreign language and their effects on teaching and on learning materials, assessment instruments, teacher training, language policies, as well as discussions about the FLT dispositive and its constituent elements, both discursive and non-discursive. We see as very exciting and promising the idea of investigating the power relations that are instituted from the knowledge constructed by tradition and by the FLT dispositive, as well as how this knowledge legitimizes the rules of power relations in the FLT dispositive, because this would require critical reflection and action from the teacher-researcher concerning their personal, academic, and social implication in relation to scientific practice.

Thus, one question - among many - that we could ask is why teachers still insist on teaching oral expression in a foreign language through activities with simulated dialogs, in which students assume hypothetical roles that they may never play? Why a student cannot be him/herself or what he/ she thinks he/she is? The problem is not restricted to the internalization of fictional roles, but also to the internalization of a particular, crystallized 
way to learn a foreign language, which prevents the student from adapting to new FLT approaches or new FLT methods. This question refers only to one example of construction of knowledge about teaching and learning a foreign language. Certainly, there are many other issues to be discussed.

We have addressed here the role of the PFL/TB in the FLT dispositive only to illustrate how a single element of this network plays such an impacting role on the ideological domination mechanism. Thus, we believe it is essential to produce knowledge about other elements of this dispositive, since the articulation of discourses and practices of all elements enables the effective functioning and the perpetuation of the dispositive, even though the sources, origin, and disruptions that the dispositive undergoes over time are unclear.

Finally, we conclude that going against almost 5000 years of tradition is practically an uphill battle; therefore, our proposal for those who wish to make a movement of disruption (and let us not mislead ourselves with this attitude, because tradition requires disruption to perpetuate itself) is to follow the path of subversion: to subvert traditional practices with new practices.

\section{Sources}

ABREU, Maria Isabel; RAMEH, Cléa. Português Contemporâneo. Washington: Georgetown University Press, 1966.

COUDRY, Pierre; PATROCÍNIO, Elizabeth F. Fala Brasil: português para estrangeiros. 17. ed. Campinas: Pontes Editores, 2011.

\section{References}

ALMEIDA FILHO, José Carlos Paes. Dimensões comunicativas no ensino de línguas. Campinas: Pontes Editores, 1993.

BORNHEIM, Gerd A. O conceito de tradição. In: BORNHEIM, Gerd A. et al. (Org.). Cultura brasileira: tradição/contradição. Rio de Janeiro: Jorge Zahar, 1987. p. 13-29.

DICKEY, Eleanor. (Org.). The Colloquia of the Hermeneumata Pseudodositheana: Colloquia Monacensia-Einsidlensia. Leidense-Stephani, \& Stephani. Cambridge; New York: Cambridge University Press, 2012.

FOUCAULT, Michel. A arqueologia do saber. 7. ed. Trans. L. F. B. Neves. Petrópolis: Vozes, 1969. 
FOUCAULT, Michel. A ordem do discurso. 9. ed. Trans. L. F. A. Sampaio. São Paulo: Loyola, 1971.

FOUCAULT, Michel. Nietzsche, Freud, Marx. In: MOTTA, M. B. (Org.). Ditos e Escritos. Arqueologia das ciências e história dos sistemas de pensamento. Trans. E. Monteiro. Rio de Janeiro: Forense Universitária, 1967. p. 40-55.

IZRE'EL, Shlomo. Canaano-Akkadian: some methodological requisites for the study of the Amarna letters from Canaan. 2007 (mimeo). Available at: < http:// www.tau.ac.il/ izreel/publications/CanAkkMethRequisites_2007>.pdf. Retrieved on: Mar. 18, 2017.

KELLY, Louis G. 25 centuries of language teaching. Massachussetts: Newbury, 1969.

LARSEN-FREEMAN, Diane. Techniques and principles in language teaching. 2. ed. Oxford: Oxford University Press, 2000.

LEFFA, Vilson J. Ensino de línguas: passado, presente e futuro. Revista de Estudos da Linguagem, Belo Horizonte, n. 20, v. 2, p. 389-411, 2012.

MATTHEWS, Peter H. The Concise Oxford Dictionary of Linguistics. Oxford: Oxford University Press, 1997.

MOITA LOPES, Luiz Paulo da. Da aplicação de linguística à linguística aplicada indisciplinar. In: ROCA, Pilar; PEREIRA, Regina Celi (Org.). Linguística Aplicada: um caminho com diferentes acessos. São Paulo: Contexto, 2009. p. 11-24.

OPPENHEIM, Adolf Leo. Ancient Mesopotamia: Portrait of a Dead Civilization. Chicago: University of Chicago Press, 1964.

PENNYCOOK, Alastair. Uma linguística aplicada transgressiva. In: MOITA LOPES, L. P. (Org.). Por uma Linguística Aplicada INdisciplinar. São Paulo: Parábola, 2006. p. 67-84.

PETERS, Michael A. Introdução: Foucault e a pesquisa educacional. In: PETERS, M. A.; BESLEY, T. Por que Foucault? Novas diretrizes para a pesquisa educacional. Porto Alegre: Artmed, 2007. p. 189-200.

TITONE, Renzo. Teaching Foreign Languages: an historical sketch. Georgetown: Georgetown University Press, 1968.

WIDDOWSON, Henry G. O ensino de linguas para comunicação. 2. ed. Trans. J. C. P. Almeida Filho. Campinas: Pontes, 1978.

Data de submissão: 30/05/2017. Data de aprovação: 30/08/2017. 